\title{
Radiotracer study of phosphorus uptake by plankton and redistribution in the water column of a small humic lake
}

\author{
Kalevi Salonen \\ Lammi Biological Station, University of Helsinki, FIN-16900 Lammi, Finland
}

Roger I. Jones

Institute of Environmental and Biological Sciences, University of Lancaster, Lancaster LA1 4YQ, England

\section{Henk De Haan}

Limnological Institute, Center for Limnology, Rijksstraatweg 6, 3631 AC Nieuwersluis, The Netherlands

\section{Mark James}

NIWAR, Freshwater Division, P.O. Box 8602, Riccarton, Christchurch, New Zealand

\begin{abstract}
The movement of $\mathbf{P}$ in the plankton of a humic lake was studied in late July within a 2-m-diameter tube. The tube enclosed water from the surfacc to below the epilimnion with the stecp vertical stratification of the lake undisturbed. $\left.{ }^{[32} \mathrm{P}\right]$ orthophosphate was mixed into the epilimnion of the enclosure and its fate followed for 2 weeks. In the epilimnion $\sim 85 \%$ of all the $\mathrm{P}$ in organisms was in Daphnia longispina, which comprised almost all the zooplankton biomass. The respective proportions for bacterioplankton and phytoplankton were $\sim 12$ and $3 \%$. Early in the experiment when the temperature of the epilimnion was $\sim 20^{\circ} \mathrm{C}$, the turnover rate of phosphate was of the order of $3 \mathrm{~h}$. By the first sampling, $3 \mathrm{~h}$ after the experiment began, bacteria showed the highest affinity for phosphate, but with this coarse time resolution, the pattern of ${ }^{32} \mathrm{P}$ incorporation into phytoplankton appeared similar. The specific radioactivity in $D$. longispina equaled that in the bacterial and algal fractions after only $2 \mathrm{~d}$, implying rapid and direct foodchain linkage between these P pools. An explanation for such rapid transfer of $\mathrm{P}$ may be that $D$. longispina consumes food with a high concentration of $P$, such as bacteria. At the end of the experiment, the specific radioactivity of the dissolved $P$ pool was considerably lower than that of the other fractions, indicating only slow exchange between part of the dissolved $\mathrm{P}$ pool and the plankton.
\end{abstract}

In temperate-zone lakes, primary production of phytoplankton is often $\mathrm{P}$ limited (Schindler 1977). However, the complexity of planktonic food chains makes $P$ cycling complicated and difficult to model. In lakes with a high allochthonous load of organic matter, the cycling of $\mathrm{P}$ seems to be further complicated. In clear-water lakes, algal excretion may be an important source of dissolved organic $C$ (DOC) (Jones et al: 1983), but in the coniferous forest zone and some tropical regions, allochthonous (mostly humic) matter often completely dominates the pool of dissolved organic matter (DOM) in water. In such cases allochthonous DOM can serve as an important C source for microheterotrophs, particularly bacteria, and renders their role in sustaining food chains comparable to that of phytoplankton (Salonen et al. 1992).

\section{Acknowledgments}

This work was supported by the Academy of Finland and Maj and Tor Nessling Foundation.
However, most substances contributing to the pool of DOM are deficient in $P$ relative to C. The biological utilization of allochthonous organic matter in humic bodies of water might thus be expected to promote the importance of bacteria as P scavengers (Stewart and Wetzel 1982) and diminish the competitive ability of phytoplankton. Currie and Kalff (1984a) proposed that an increased supply of allochthonous organic $\mathrm{C}$ influences bacterial biomass positively and algal biomass negatively. Ryhänen (1968) found increased decomposition of humic substances with mineral nutrient additions, but Jones (1990) found no evidence that high allochthonous DOM, in the absence of severe $\mathrm{P}$ deficiency, shifts the balance of plankton phosphate uptake toward bacteria at the expense of algae. He concluded that biological P transformations may be modified in humic lakes by an increased relative abundance of bacteria over algae.

The availability of $P$ to both bacteria and algae is potentially affected by abiotic inter- 
actions between phosphate and humic matter. Dissolved inorganic P (DIP) seems to be partly, but reversibly, bound by humic compounds and Fe (Francko 1986, 1990; De Haan et al. 1990). The exact biological consequences of this phenomenon are still uncertain. Such binding evidently decreases the concentration of available free orthophosphates, but later release of the bound phosphate when ambient free phosphate is depleted may sustain available free phosphate at low concentrations (Jones 1990), favoring organisms like bacteria with a high affinity for phosphate. This hypothesis is consistent with the findings of Stewart and Wetzel (1982) that DOM in water favors bacteria over algae.

It may be only in lakes with higher concentrations of $\mathrm{P}$ that phytoplankton acquire a large proportion of their $\mathrm{P}$ as phosphate (Currie et al. 1986), while in less productive lakes bacteria are responsible for most phosphate uptake (Rigler 1956; Currie and Kalff 1984a). Currie and Kalff (1984b) suggested that this paradox might be explained by substantial excretion by bacterioplankton of dissolved organic $P$ (DOP) which is subsequently used by phytoplankton. However, Heath (1986) concluded that DOP compounds are not a major source of phosphate for phytoplankton, at least at the height of the growing season, and it remains unclear how algae satisfy their $P$ requirements in the epilimnion of humic waters. One mechanism would be by regular vertical migration to deeper, phosphate-rich waters by the motile algae which are often dominant in humic waters (Jones 1991).

Francko (1986, 1990), with a continuum model, has reconciled some major influences of DOM on P cycling and has stressed the complex nature of epilimnetic $P$ cycling. However, new evidence on the importance of DOM for planktonic food chains, on the role of microheterotrophs in the cycling of nutricnts (Andersen et al. 1986), and on some behavioral aspects of plankton means that complete understanding of $\mathbf{P}$ cycling remains as elusive as ever. As a further step toward that understanding, we studied the movements of $P$ in situ in a small highly humic lake with a relatively simple plankton community. An enclosure was established with an undisturbed, vertical distribution of organisms as well as undisturbed physical and chemical stratifica- tion in the water column. Such a system allows isotope addition for tracing $P$ transfers and is more realistic than batch experiments with homogeneous water samples, so it potentially yields more realistic information about $P$ movements in the lake.

\section{Methods}

The experiment was done at Mekkojärvi, a small (120 m long, $40 \mathrm{~m}$ wide, $4 \mathrm{~m}$ deep) headwater lake in the Evo region of southern Finland. This lake was selected because of its humic water (color, 300-600 mg Pt liter ${ }^{-1}$ ), its exceptionally steep stratification, and the amount of background information available about it (e.g. Salonen et al. 1992 and references cited therein).

In the middle of the lake, an undisturbed water column was isolated with a $2.5-\mathrm{m}$-long, 2 -m-diameter, cylindrical plastic $(80 \%$ polyethylene, $20 \%$ vinyl acetate) open-bottom tube, which was lowered slowly into the water through a preinstalled floating frame anchored tightly to trees on the shore. With this arrangement, the natural vertical migration and sedimentation of organisms and upward diffusion of substances from the sediment were not disturbed. Firm anchoring of the frame, its low emergence above the water, and the absence of waves in this sheltered location kept the tube very steady. Although the bottom of the tube was open, it extended deep enough into the anoxic water layer that epilimnetic organisms had no opportunity to escape from the enclosure. The probability of bird defecation in the enclosure was low. Gulls or other birds that might perch on the margin of the enclosure were absent from this small lake, and no signs of bird droppings were detected on the frame.

The enclosure was installed on 19 July 1988 and left for $24 \mathrm{~h}$ to ensure equilibration between conditions in the tube and those outside. On 20 July at $\sim 1100$ hours solar time, $37 \mathrm{MBq}$ of carrier-free $\left[{ }^{32} \mathrm{P}\right]$ orthophosphate (in dilute $\mathrm{HCl}$ ) was added to the epilimnion in the enclosure. To ensure an even distribution of label in the epilimnion, we immediately mixed the water with a wooden paddle. The enclosure was then sampled at successively greater time intervals during the following 2 weeks. The vertical distribution of the label was monitored during the experiment by measuring total radioactivity in samples taken with a pneu- 
matic syringe sampler (Blakar 1979). At the end of the experiment (14 d), large volumes of water from $0.2-\mathrm{m}$ depth intervals down the water column were obtained by pumping water through a $10-\mathrm{mm}$-diameter flexible hose.

Samples for determining radioactivities in different size fractions were taken with a 50mm-diameter acrylic plastic tube. The tube was lowered slowly to a depth of $0.5 \mathrm{~m}$ and its upper end was closed with a rubber stopper. Then the lower end of the tube was lifted to near the surface, closed by a rubber-gloved hand, and drained into a polyethylene bucket. Three $0.5-\mathrm{m}$-long replicate water columns from the enclosure were mixed together in the bucket to provide the final sample. According to the results of Salonen and James (unpubl. data) obtained from the same lake 2 weeks later, at least $80 \%$ of Daphnia were within the sampling zone.

In the laboratory, water was filtered by gravity through a $50-\mu \mathrm{m}-\mathrm{mesh}$ plankton net. The cladoceran, Daphnia longispina, formed practically all the metazoan zooplankton biomass in the pelagial zone of the lake. Daphnia individuals retained on the net were flushed into a funnel and filtered onto a $3-\mu \mathrm{m}$ pore-size, 47-mm-diameter silver filter with a grid. As soon as the water passed the filter, the vacuum was released and the silver filter was removed onto a wet glass-fiber filter on a plastic Petri dish. With this arrangement, the animals remained covered by a thin film of water but were unable to move.

Six replicates, each with 10 Daphnia, were picked randomly under a dissecting microscope into an acid-washed glass liquid scintillation vial containing $5 \mathrm{ml}$ of deionized water and radioactivity was assayed. Although the radioactivity of individual Daphnia was obtained from $0.5-\mathrm{m}$ tube samples, that was considered inadequate for quantitative population estimates. Furthermore, D. longispina is known to migrate vertically, which would make results sensitive to the time of sampling. Because there was no reason to suppose that animals below the depth of our routine sampling did not participate in the movements of $P$ in the uppermost $0.5 \mathrm{~m}$, we calculated results for the whole population. We obtained precise estimates for the population density of Daphnia by sampling the whole lake at 6 -h intervals during $1 \mathrm{~d}$ (James and Salonen 1991). Our results are based on the assumption that the biomass of $D$. longispina stayed the same during the course of the experiment. This assumption is probably not critical during the first few days of the experiment, and it does not affect the specific radioactivities at all. Until the last day, sampling from the enclosure did not markedly affect the community, because only $\sim 1 \%$ of water in the uppermost water column was removed.

To determine radioactivity and $P$ in the phytoplankton size fraction $(1-50 \mu \mathrm{m})$, we passed $200 \mathrm{ml}$ of $50-\mu \mathrm{m}$ filtrate through a $1-\mu \mathrm{m}$ poresize Nuclepore filter which was then immersed in $5 \mathrm{ml}$ of deionized water in an acid-washed liquid scintillation vial. In a similar way, 25 $\mathrm{ml}$ of $1-\mu \mathrm{m}$ filtrate was passed (vacuum, 25 $\mathrm{kPa}$ ) through $0.2-\mu \mathrm{m}$ pore-size filters to obtain results for the bacterial size fraction $(0.2-1 \mu \mathrm{m})$. Our observations with a fluorescence microscope over several years have never indicated the presence of autotrophic picoplankton in Mekkojärvi, but that was not verified during this experiment. Radioactivity and $\mathrm{P}$ in the dissolved fraction $(<0.2 \mu \mathrm{m})$ were determined from $5 \mathrm{ml}$ of the $<0.2-\mu \mathrm{m}$ filtrate.

All radioactivities were measured by a LKB Wallac Ultrobeta 1200 liquid scintillation counter with Cerenkov counting and results corrected for decay to standardize radioactivity with that at the beginning of the experiment. After determination of radioactivity, all samples were frozen in closed liquid scintillation vials and their $P$ concentration mcasured after 8 months, when the maximum radioactivity in any sample had decreased to a level equivalent to only about twice that of the background. Samples were dried at $105^{\circ} \mathrm{C}$ in a heating cabinet and then ignited at $450^{\circ} \mathrm{C}$ overnight. Phosphate in the ash was dissolved in $5 \mathrm{ml}$ of $0.015 \mathrm{M} \mathrm{H}_{2} \mathrm{SO}_{4}$ and determined with an AKEA autoanalyzer according to Murphy and Riley (1962). The results were corrected for blanks of Nuclepore filters.

On two occasions we used a Dionex 2000 ion chromatograph (with AS4A column and micromembrane suppressor; sample, $0.5 \mathrm{ml}$ ) to isolate phosphate from other species of dissolved $P$. The elution time for phosphate obtained from standards was verified with dilute $\left[{ }^{32} \mathrm{P}\right]$ phosphate. Using the elution time, we collected the phosphate peak and counted its radioactivity. For a third set of samples with 
even lower radioactivity, we tried to concentrate phosphate with a concentrator column but found that the high humic concentration immediately destroyed it.

Particulate $\mathrm{C}$ collected on preignited, Whatman $\mathrm{GF} / \mathrm{F}$ (bacterial fractions) or $\mathrm{GF} / \mathrm{C}$ (field samples) glass-fiber filters was determined with high-temperature combustion (Salonen 1979) and particulate $P$ was determined as described above. Particulate $\mathrm{N}$ on filters was determined with persulfate digestion. Temperature and oxygen profiles were measured in the field with a YSI probe.

Bacteria were counted with acriflavine staining and epifluorescent microscopy according to Bergström et al. (1986), and algae were counted with a settling chamber method and an inverted microscope. Material sedimenting down the water column was collected with a $115-\mathrm{mm}$-diameter closed funnel fixed in the middle of the enclosure at a depth of $2.5 \mathrm{~m}$. The ratio between the diameter and height of the funnel was only $\sim 2$, but the strong vertical stratification of temperature and the sheltered position of the lake make resuspension of sedimented material unlikely. The funnel was recovered at the end of the experiment and the settled sediment emptied into a bucket and transported to the laboratory. Sedimented matter was homogenized by vigorous stirring and five subsamples were filtered on glass-fiber filters which were then placed in $5 \mathrm{ml}$ of deionized water in a vial and assayed for radioactivity.

\section{Results}

At the beginning of the experiment in late July, Mekkojärvi was steeply stratified with an epilimnion $<0.5 \mathrm{~m}$ thick. The underlying hypolimnion was anoxic and its chemical (Fig. 1) and biological characteristics were strikingly different from those near the surface. The progressive increase of conductivity with depth reflects incomplete mixing of water in spring and sedimentation of particulates with subsequent leaching of electrolytes. A similar trend of increasing concentration with depth was ob- served in the vertical distributions of measurcd cations. Fe concentration was very high, associated with the high concentration of humic matter (water color, $400 \mathrm{mg} \mathrm{Pt} \mathrm{liter}{ }^{-1}$ ) and, in the hypolimnion, with the absence of oxygen. In the hypolimnion, $\mathrm{pH}$ increased toward the bottom due to sulfate reduction.

Phosphate concentration in the epilimnion was $\sim 4 \mu \mathrm{g} \mathrm{P}$ liter $^{-1}$, and this low concentration extended to about twice the depth of the oxic water. The concentration of $\mathrm{NO}_{2}+\mathrm{NO}_{3}$ was about the same throughout the water column, but $\mathrm{NH}_{4}$ increased below 1.6-m depth, coinciding with the maximum density of photosynthetic bacteria which probably contributed significantly to the marked increase in particulate organic $\mathrm{C}(\mathrm{POC})$ in the hypolimnion (Fig. 1). Two days before the experiment the $C: N$ : $P$ atomic ratio of DOM in the $0-1-\mathrm{m}$ water layer was rather uniform $(4,955: 111: 1)$ and indicated low concentration of nutrients in relation to $\mathrm{C}$. In the hypolimnion, DOP increased severalfold while dissolved organic $\mathrm{N}$ (DON) decreased to about half $(1.8-2 \mathrm{~m})$ that in the epilimnion, leading to a $\mathrm{C}: \mathrm{N}: \mathrm{P}$ ratio of $1,200: 33: 1$. In the hypolimnion, $C: N$ was, thus, similar to $C: N$ in the epilimnion but $N$ : $\mathrm{P}$ was more favorable, although still indicating $P$ deficiency in DOM. In the $0.5-\mathrm{m}$ water layer from the surface of the enclosure, the $\mathrm{N}: \mathrm{P}$ ratio in DOM was similar to that in the lake. It was 95 at the beginning of the experiment and increased toward the end of the experiment (to 150 after 2 weeks), indicating slightly increased $\mathrm{P}$ deficiency. In the lake the ratio did not show an increasing trend.

After the initial mixing of $\left[{ }^{32} \mathrm{P}\right]$ phosphate into the epilimnion of the enclosure, the vertical distribution of temperature closely matched that measured in the lake. However, there had been an increase of $\sim 0.2^{\circ} \mathrm{C}$ at $0.6-$ $0.8-\mathrm{m}$ depth which coincided with a slightly increased concentration of oxygen (Fig. 1). During the experiment, epilimnetic water cooled, and convective mixing moved the thermocline slightly deeper (Fig. 1). Probably neither the diurnal convective mixing nor our

Fig. 1. The vertical distributions of temperature, oxygen, conductivity, pH, C, and various ions in Mekkojärvi and in the experimental enclosure (encl) at the beginning and the end of the experiment. TP results in the hypolimnion are probably underestimates due to anoxia and inefticient sampling of zooplankton. 

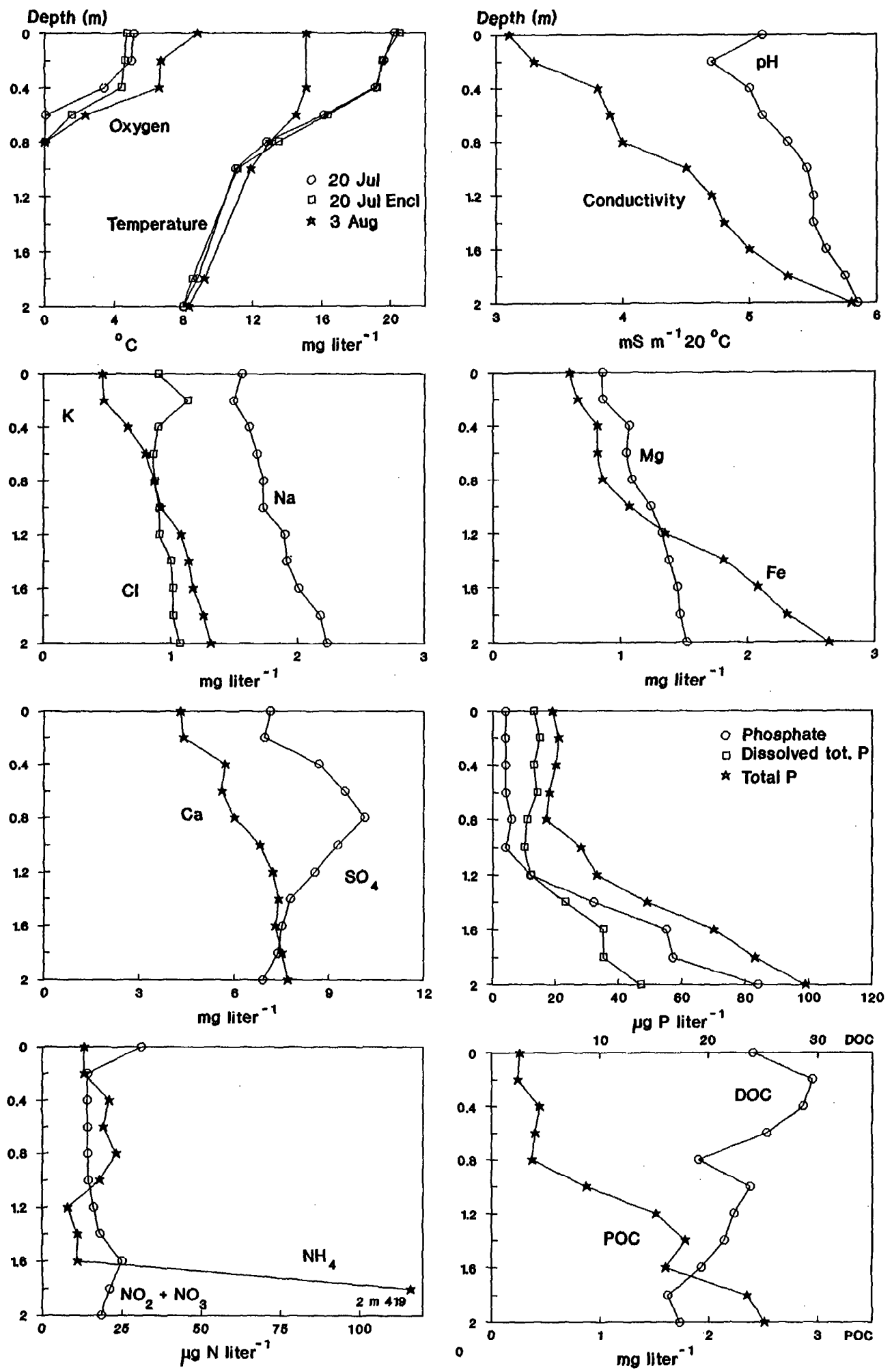

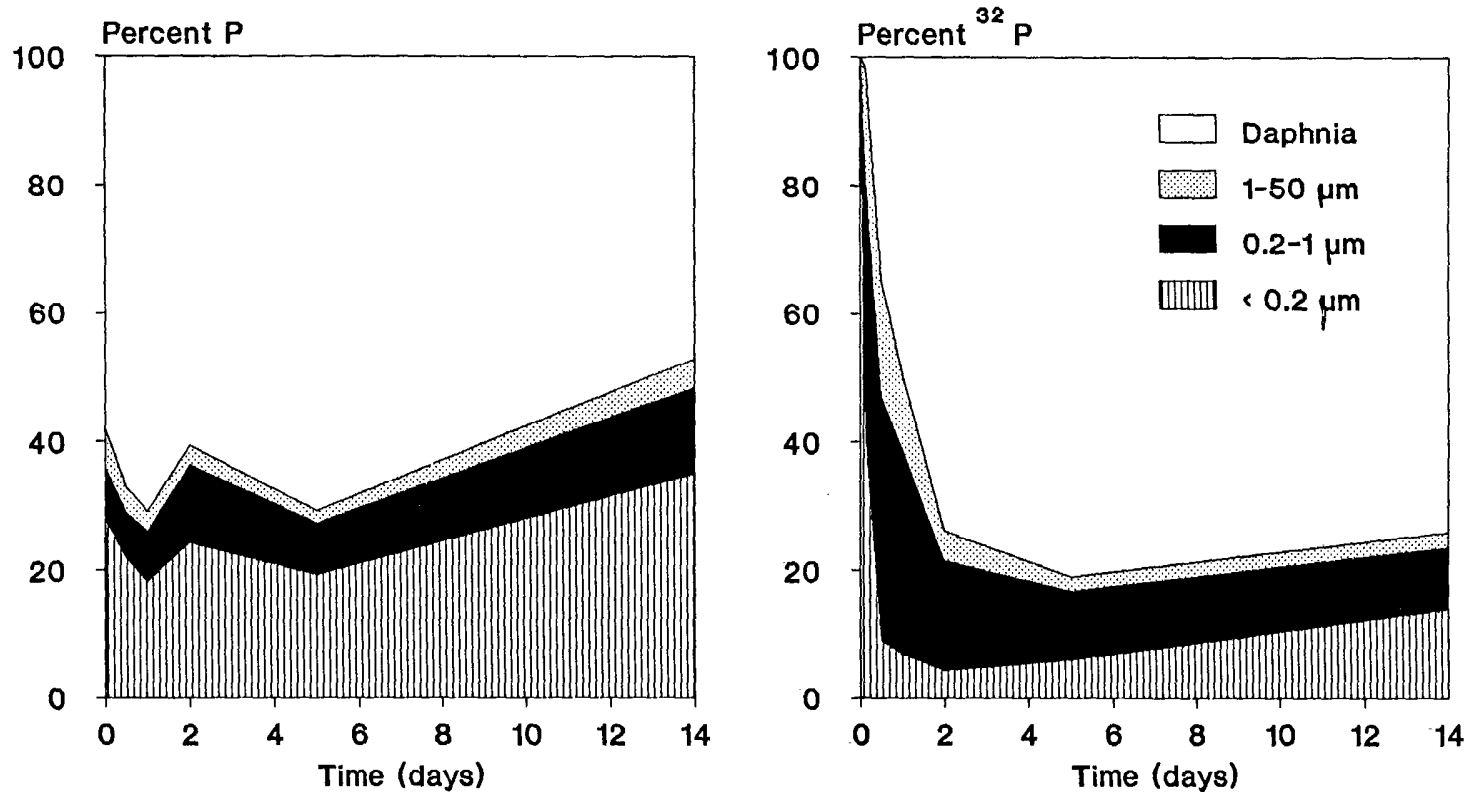

Fig. 2. Relative distribution of $\mathrm{P}$ and ${ }^{32} \mathrm{P}$ among size fractions in the $0.5-\mathrm{m}$ epilimnion of the enclosure.

artificial mixing at the beginning of the experiment had any effect on the concentrations of nutrients in the epilimnion or on the results, since the concentrations of nutrients in the metalimnion were similar to those in the epilimnion. Although the first sampling yielded a 2-fold higher phosphate concentration than during the rest of the experiment, this result is based on only one duplicate determination from one sample.

Metazoan zooplankton biomass was almost exclusively composed of $D$. longispina, which was very abundant $\left(\sim 230\right.$ ind. liter ${ }^{-1}$ in the epilimnion). Most of the population (65-86\% depending on time of day) was in the uppermost $0.5 \mathrm{~m}$, and practically all was at $<1 \mathrm{~m}$ (Salonen and James unpubl.). In the epilimnion, bacterioplankton was less abundant (mean $\pm \mathrm{SD} ; 2.2 \pm 0.3 \times 10^{6}$ cells $\mathrm{ml}^{-1}$ at the beginning of the experiment) than observed in Mekkojärvi by Kankaala (1988). Most bacteria were small (mean diam, $0.4 \mu \mathrm{m}$ ). Consequently, cells $<0.064 \mu \mathrm{m}^{3}$ contributed only $14 \%$ of total biomass, although their share in numbers was $56 \%$. The low population density of bacteria probably resulted from the high density of $D$. longispina which, together with bacterivorous flagellates, is a significant grazer of bacteria in Mekkojärvi (Kankaala 1988). In samples taken $5 \mathrm{~d}$ after the beginning of the experiment, $>90 \%$ of phytoplankton biomass in the epilimnion was composed of Cryptomonas and Mallomonas species.

The largest $\mathrm{P}$ pool in the epilimnion was in D. longispina (35-50 $\mu \mathrm{g} \mathrm{P}$ liter $\left.{ }^{-1}\right)$, which represented $50-70 \%$ of total $P$ (TP) (Fig. 2). In fact the $\mathrm{P}$ level in $D$. longispina may not have changed during the experiment, since the proportion at the end of the experiment is uncertain due to unknown problems in determining $P$ in Daphnia samples from the last date (Table 1). The dissolved fraction contained $\sim 20 \%$ of the TP, which was 2-3 times more than in the $0.2-1-\mu \mathrm{m}$ fraction (Fig. 2). In the $1-50-\mu \mathrm{m}$ fraction the respective proportion was $<5 \%$.

Some time-dependent changes were observed in different pools of $P$ (Fig. 3). In the dissolved fraction, $\mathrm{P}$ decreased from the beginning of the experiment and then remained stable. A similar trend was observed in the 1$50-\mu \mathrm{m}$ fraction. However, in the $0.2-1-\mu \mathrm{m}$ fraction $\mathbf{P}$ increased slightly but clearly at the beginning of the experiment. The results for $\mathrm{C}, \mathrm{N}$, and $\mathrm{P}$, obtained by passing the $0.2-1-$ $\mu \mathrm{m}$ fraction through Whatman GF/F glass-fiber filters, showed a similar trend (Fig. 4), al- 
Table 1. The reliability of the determinations of $\mathbf{P}$ concentrations, radioactivities, and spccific radioactivities in the size fractions after different sampling intervals. The figures are given as $95 \%$ C.L. $(t \times \mathrm{SD} / n$, expressed as $\%$ of mean) based on triplicate determinations except for Daphnia where six groups, each consisting of 10 randomly picked individuals, were determined.

\begin{tabular}{lrrrrrr}
\hline \hline & \multicolumn{5}{c}{ Sampling time (h) } \\
\cline { 2 - 5 } & 3 & 12 & 24 & 48 & 120 & 336 \\
\hline \multicolumn{7}{c}{ P concentration } \\
$<0.2 \mu \mathrm{m}$ & 15 & 32 & 20 & 20 & 20 & 20 \\
$0.2-1 \mu \mathrm{m}$ & 10 & 20 & 7 & 0 & 10 & 10 \\
$>1 \mu \mathrm{m}$ & 40 & 22 & 5 & 25 & 32 & 32 \\
Daphnia & 97 & 32 & 24 & 24 & 66 & $89^{*}$ \\
& \multicolumn{7}{c}{32 P radioactivity } & & \\
$<0.2 \mu \mathrm{m}$ & 20 & 5 & 5 & 5 & 5 & 5 \\
$0.2-1 \mu \mathrm{m}$ & 15 & 20 & 7 & 5 & 2 & 10 \\
$>1 \mu \mathrm{m}$ & 15 & 15 & 7 & 7 & 5 & 5 \\
Daphnia & 14 & 22 & 23 & 11 & 26 & 38 \\
& \multicolumn{7}{c}{ Specific radioactivity } & & \\
$<0.2 \mu \mathrm{m}$ & 32 & 30 & 15 & 20 & 15 & 47 \\
$0.2-1 \mu \mathrm{m}$ & 27 & 11 & 17 & 7 & 14 & 13 \\
$>1 \mu \mathrm{m}$ & 20 & 12 & 7 & 14 & 26 & 27 \\
Daphnia & 60 & 43 & 21 & 29 & 29 & 89 \\
\hline
\end{tabular}

* Three replicates (two replicates abandoned because they were ncarly 10 times higher than in any samples).

though the estimated concentration of $P$ was lower (Fig. 4) than that measured on Nuclepore filters (Fig. 3). This difference may be explained by the small size of bacteria in the plankton at this time (see above) and, hence, their partial passage through $\mathrm{GF} / \mathrm{F}$ filters. However, assuming that there was no systematic difference in elemental atomic ratios between cells retained on and passing through the GF/F filter, the results can be used to estimate nutrient satiation of bacteria.

At the beginning of the experiment, the added ${ }^{32} \mathrm{P}$ was entirely in the epilimnion (Fig. 5). The intense color of Mekkojärvi water produces strong daytime heating at the surface followed by cooling and convective mixing at night, so a rather uniform distribution of label in the epilimnion (with the probable exception of zooplankton) was maintained. However, part of the label gradually moved into the hypolimnion. After $5 \mathrm{~d}$ (data not shown), radioactivity in the epilimnion was still discernible but, after $14 \mathrm{~d}$, slightly higher levels of radioactivity were found in the upper hypolimnion (Fig. 5). The sum of radioactivity (corrected for decay) of ${ }^{32} \mathrm{P}$ in different compartments in the epilimnion remained at a similar level for

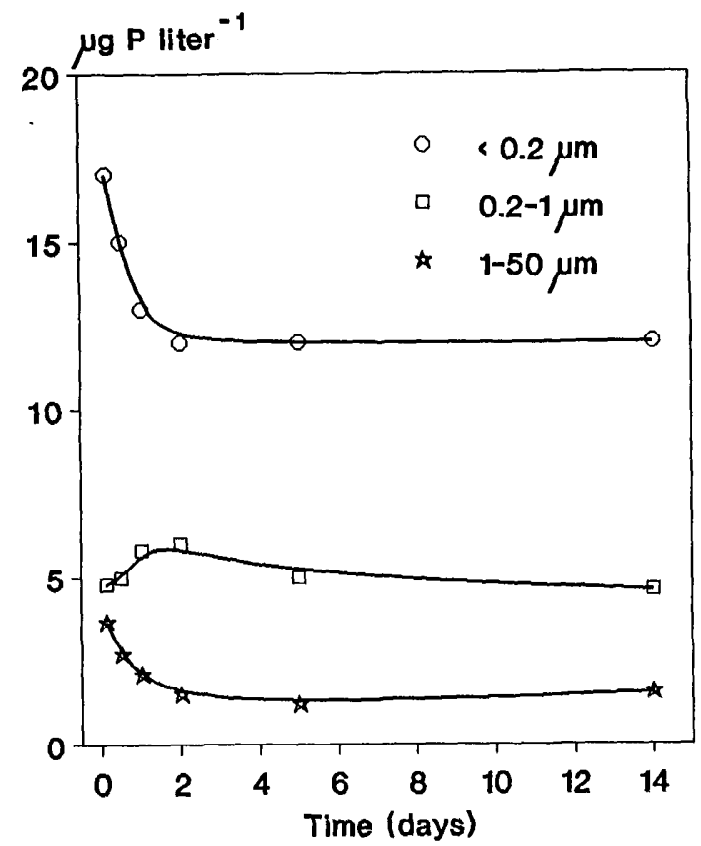

Fig. 3. Time-course of $P$ concentration in different size fractions from the $0.5-\mathrm{m}$ epilimnion of the enclosure. The determinations were made on particles retained on $\mathrm{Nu}$ clepore filters.

$5 \mathrm{~d}$. The variation in the total radioactivity during this time was mostly due to variation in the results for D. longispina. By the end of the experiment, about three-quarters of the label had been lost from the uppermost $0.5 \mathrm{~m}$ of the water. Tests with pieces of the plastic from which the enclosure was constructed showed negligible absorbance of ${ }^{32} \mathrm{PO}_{4}$.

After $1 \mathrm{~d}$, the sum of radioactivities found in the different size fractions in samples taken from the epilimnion with a $0.5-\mathrm{m}$ tube was about twice the integral in the total samples taken with the close-interval syringe sampler. The ability of zooplankton (containing a high proportion of the total label) to avoid capture by the syringe sampler probably explains this difference.

At the end of the experiment, the depthintegrated radioactivity from all close-interval samples indicated $46 \%$ loss of ${ }^{32} \mathrm{P}$ from the $2-\mathrm{m}$ water column in the enclosure as compared to the similarly measured radioactivity at the beginning of the experiment. This may be an overestimate because zooplankton contained little ${ }^{32} \mathrm{P}$ at the beginning of the exper- 

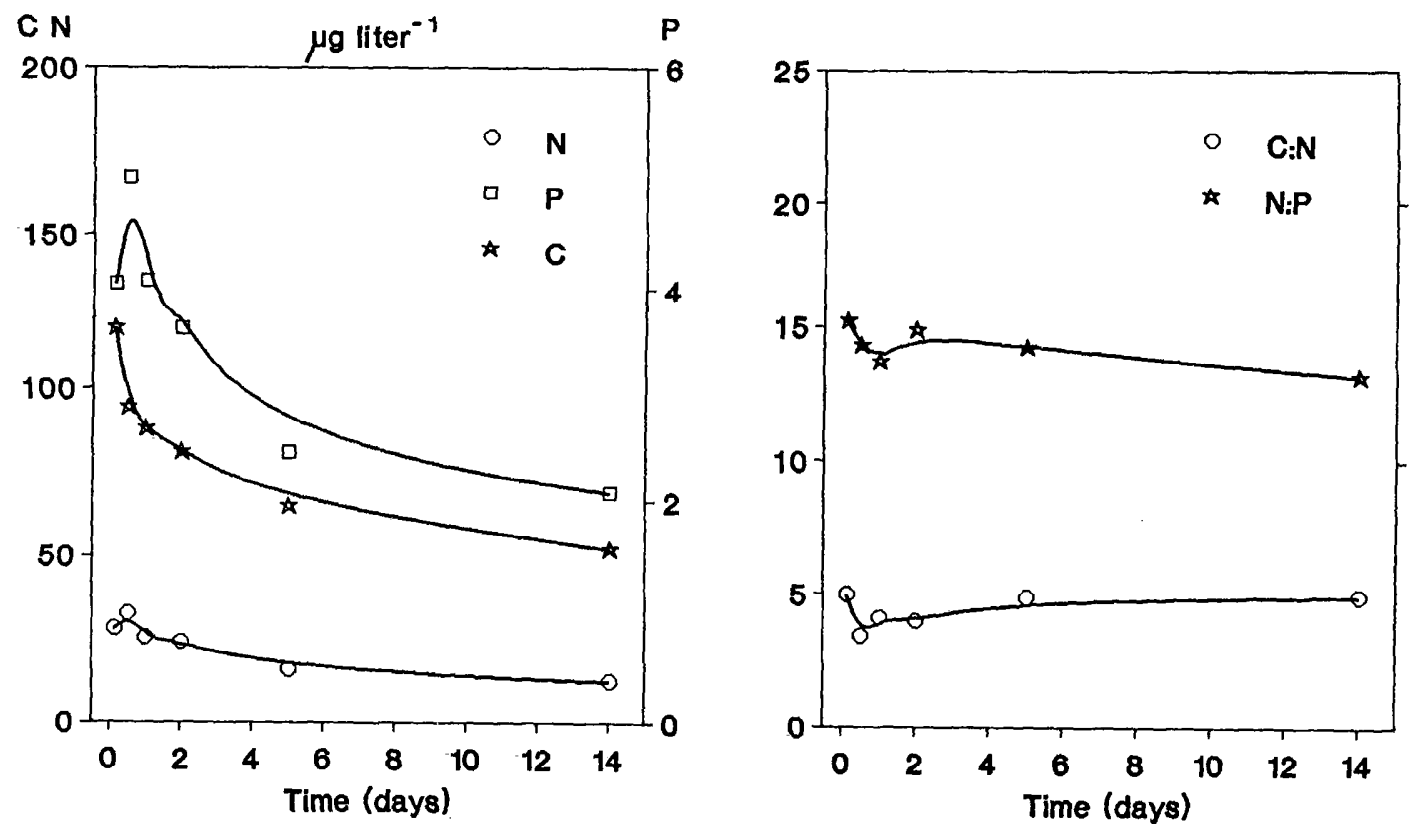

Fig. 4. $\mathrm{P}, \mathrm{N}$, and $\mathrm{C}$ concentrations in the $<1-\mu \mathrm{m}$ particulate size fraction filtered on ignited GF/F glass-fiber filters and $C: N$ and $N: P$ ratios during the expcriment in water from the epilimnion.

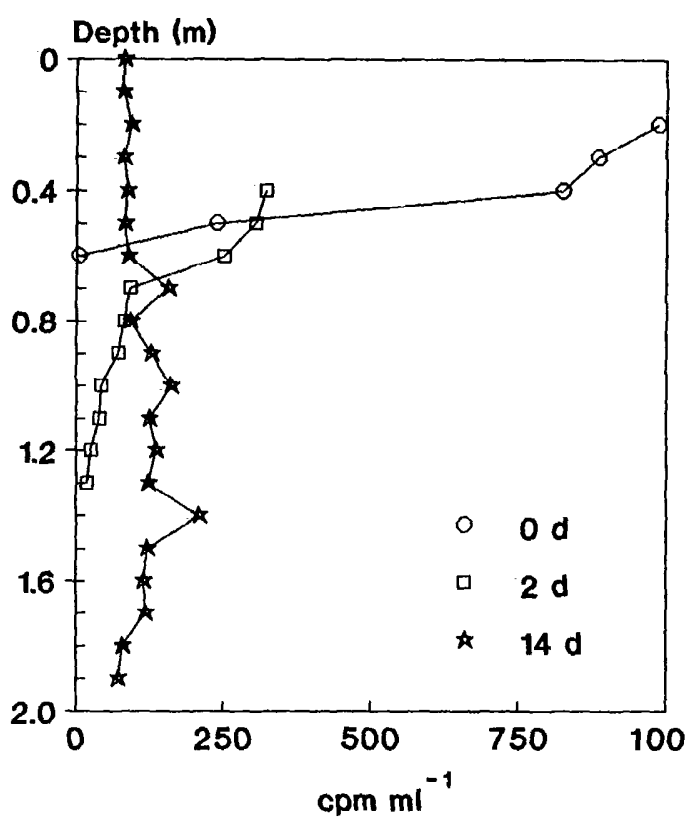

Fig. 5. Vertical distribution of ${ }^{32} \mathrm{P}$ in the enclosure at the start, after $2 \mathrm{~d}$, and after $14 \mathrm{~d}$ as revealed by closeinterval pneumatic sampling. iment, whereas labeling was very high at the end of the experiment, thus decreasing the efficiency of sampling total ${ }^{32} \mathrm{P}$ by the close-interval syringe sampler. After the same time interval, $40 \%$ of ${ }^{32} \mathrm{P}$ was found in sedimented matter. This proportion is likely to be an underestimate, since sedimented matter may have released some of its $\mathbf{P}$ during decomposition in the sedimentation funnel. In spite of uncertainty in both estimates of ${ }^{32} \mathrm{P}$ loss during the experiment, the values from these independent methods of determining ${ }^{32} \mathrm{P}$ loss from the $2-\mathrm{m}$ water column are in good agreement.

More detailed vertical distributions of ${ }^{32} \mathrm{P}$ (excluding zooplankton) were determined at the end of the experiment (Fig. 6). In all fractions the distribution was uniform down to $0.8-\mathrm{m}$ depth, as expected from the vertical stratification of temperature. The highest radioactivity in the $0.2-1-\mu \mathrm{m}$ fraction in the epilimnion may reflect the low sedimentation rate of free-living bacteria. In particles $>1 \mu \mathrm{m}$ there was a slight ${ }^{32} \mathrm{P}$ maximum at $\sim 1.6-\mathrm{m}$ depth that was probably due to incorporation within a population peak of photosynthetic bacteria at this depth. However, the higher "cold" phosphate concentration available in the hy- 
Depth $(m)$

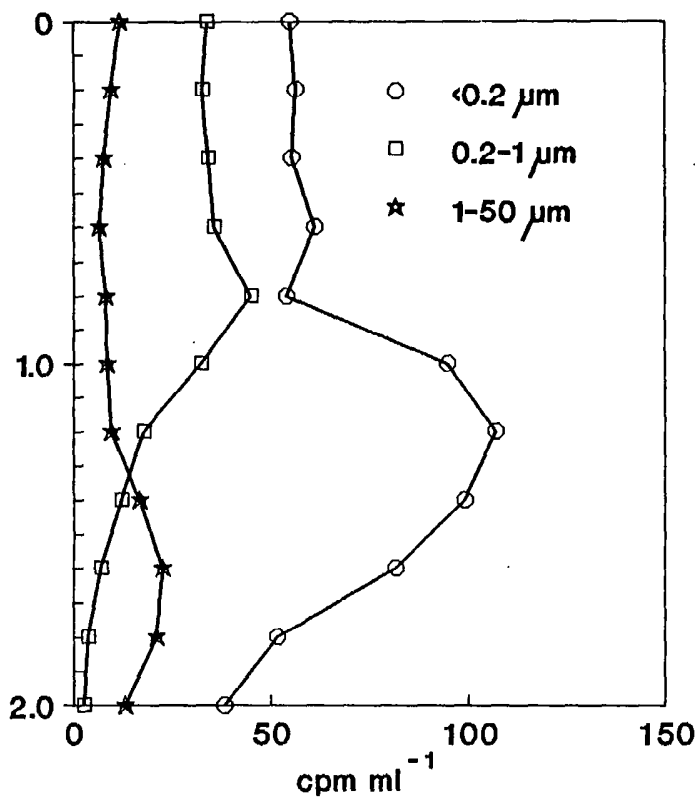

Fig. 6. Vertical distributions of different size fractions in the enclosure as revealed by sampling with a vacuum pump from different depths of the enclosure at the end of the cxperiment (14 d).

polimnion evidently reduced the incorporation of ${ }^{32} \mathrm{P}$ in hypolimnetic organisms. A striking maximum in the dissolved fraction was observed in the upper hypolimnion.

At the temperature of $\sim 20^{\circ} \mathrm{C}$ in the epilimnion, the added [ $\left.{ }^{32} \mathrm{P}\right]$ phosphate was rapidly taken up by organisms. Three hours after the beginning of the experiment, only $\sim 40 \%$ of ${ }^{32} \mathrm{P}$ was left in the dissolved pool, and after 12 $\mathrm{h}$ this was reduced to $<10 \%$ (Fig. 2). The observed initial decrease in the radioactivity of the $<0.2-\mu \mathrm{m}$ pool means a turnover time of $\sim 3 \mathrm{~h}$ (calculated as the reciprocal of the slope of the logarithmic decrease of the percentage of dissolved $P$ remaining).

The determinations of molybdate reactive $P$ from the enclosure with an ion chromatograph (Table 2) and those made before the experiment with an autoanalyzer (Fig. 1) yielded similar results. However, this comparison is not fully justified because the samples were not taken at the same time. The small proportion of dissolved ${ }^{32} \mathrm{P}$ after $2 \mathrm{~d}$ (Fig. 2) probably reflects an approach to a balanced distribution of label in the three smallest size
Table 2. Free phosphate concentrations as determined dircctly by ion chromatography from $0.2-\mu \mathrm{m}$ filtercd epilimnetic water and specific radioactivity of free phosphate $P$.

\begin{tabular}{ccc}
$\begin{array}{c}\text { Time } \\
\text { (h) }\end{array}$ & $\begin{array}{c}\text { Phosphate } \\
\left(\mu \mathrm{g} \text { P liter }{ }^{\prime}\right)\end{array}$ & cpm (ng P) \\
\hline 3 & 4.3 & 151 \\
48 & 4.8 & - \\
120 & 4.7 & - \\
\hline
\end{tabular}

fractions. Although movement of ${ }^{32} \mathrm{P}$ into deeper water layers (Fig. 5) and large confidence limits attached to some zooplankton samples (Table 1) make interpretation of the results after 2 weeks uncertain, the steady increase in the proportion of dissolved ${ }^{32} \mathrm{P}$ after $2 \mathrm{~d}$ may reflect incorporation of ${ }^{32} \mathrm{P}$ into biologically less available DOP. That would be consistent with the markedly higher proportion of the dissolved fraction in TP than in radioactivity (Fig. 2).

The most intensive uptake of ${ }^{32} \mathrm{P}$ was into the $0.2-1-\mu \mathrm{m}$ fraction, which reached its maximum radioactivity $9 \mathrm{~h}$ after the experiment began (Fig. 7). In the $1-50-\mu \mathrm{m}$ size fraction the accumulation of label was slower, but its maximum was observed at the same time as that of the 0.2-1- $\mu \mathrm{m}$ fraction. In D. longispina the highest radioactivity was found $\sim 2 \mathrm{~d}$ later, when radioactivities in the smaller particles were already decreasing. The initial rates of decrease from the maximum radioactivity were different between different size fractions. The highest loss rate of $\sim 60 \% \mathrm{~d}^{-1}$ was in the $1-50$ $\mu \mathrm{m}$ fraction-consistent with the observed decrease in the $P$ content of the same fraction (Fig. 3). Similarly, the slight increase in the $P$ content of bacteria (Fig. 3) may have compensated for the loss rate $(\sim 34 \%)$ of ${ }^{32} \mathrm{P}$ from the $0.2-1-\mu \mathrm{m}$ fraction (Fig. 7). The respective value $(\sim 12 \%)$ for $D$. longispina was lowest but, due to the dominant contribution of Daphnia to TP, about the same as that calculated for TP during the whole experiment.

The distribution of label between the particulate size fractions was initially highest $(>60 \%)$ in the $0.2-1-\mu \mathrm{m}$ fraction (Fig. 2), but fell rapidly to $\sim 10 \%$. In the $1-50-\mu \mathrm{m}$ fraction, the maximum proportion was only $\sim 30 \%$ and also occurred $3 \mathrm{~h}$ after the experiment started. The $1-50-\mu \mathrm{m}$ size fraction then contained about half as much ${ }^{32} \mathrm{P}$ as the $0.2-1-\mu \mathrm{m}$ size 

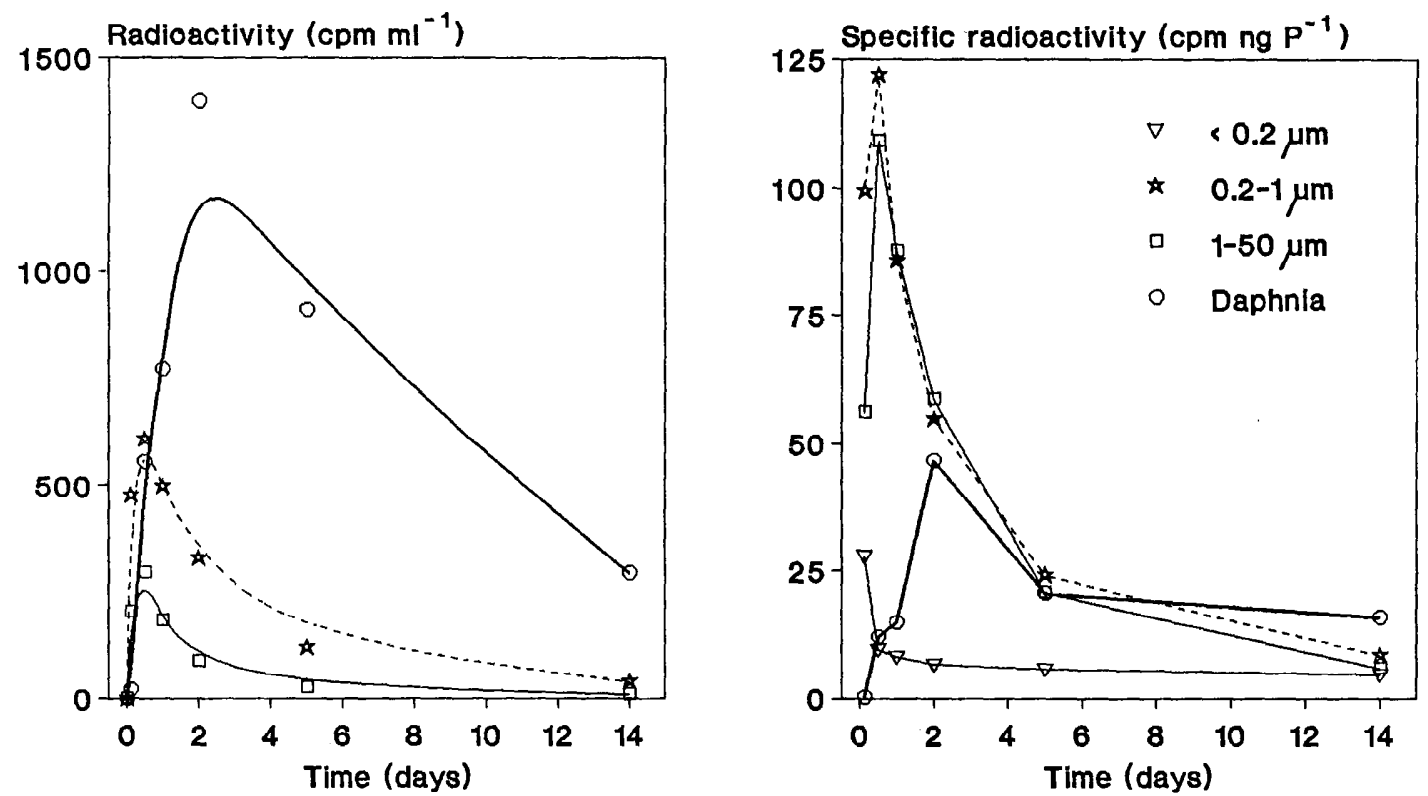

Fig. 7. Time-course of radioactivities and specific radioactivities of $\mathrm{P}$ in different size fractions in the $0.5-\mathrm{m}$ epilimnion of the enclosure.

fraction, but later this fell to $\sim 20-25 \%$, only $\sim 2 \%$ of the total label. The proportion of ${ }^{32} \mathrm{P}$ in $D$. longispina reached $\sim 80 \%$ of all particulate ${ }^{32} \mathrm{P}$ after $5 \mathrm{~d}$ (Fig. 2)-consistent with its very high proportion in TP in Mekkojärvi during this period (Fig. 2). Relatively stable proportions of radioactivity in organisms after 5 d suggest a balanced distribution of label, and hence a rather rapid turnover of $P$ between all trophic levels.

The precision of the radioactivities and $\mathrm{P}$ concentrations in different size fractions was generally good (Table 1). Even when the variation of some $P$ results was large, since both determinations were made from exactly the same samples, the specific radioactivities still showed rather low variation and smooth trends during the experiment (Fig. 7). The specific radioactivities showed time-courses similar to those of the radioactivities of $P$ in the different size fractions. The specific radioactivity of $P$ in particles increased most rapidly and reached the highest level in the $0.2-1-\mu \mathrm{m}$ fraction, indicating a higher affinity for phosphate and more rapid turnover time than in other size classes.

Nevertheless, after only $12 \mathrm{~h}$, the specific radioactivity in the $1-50-\mu \mathrm{m}$ fraction closely matched that of the $0.2-1-\mu \mathrm{m}$ fraction. In fact, the sampling intervals at the beginning of the experiment were too long to adequately differentiate between time-courses in the 0.2-1and $1-50-\mu \mathrm{m}$ size fractions. In spite of its very much larger body size, after only $2 \mathrm{~d}$ the specific radioactivity in Daphnia was similar to those in the other fractions. After 2 weeks all $P$ pools, including dissolved, showed about the same specific radioactivity. The higher value for Daphnia at the last sampling (Fig. 7) is unreliable due to exceptional variation in $\mathrm{P}$ determination, which resulted in large confidence limits (Table 1).

Due to the decrease in total label in the epilimnion, sedimentation, and appearance of hypolimnetic ${ }^{32} \mathrm{P}$ pools, the specific radioactivities measured from the final sampling are generally less reliable. Although the specific radioactivity of dissolved $\mathrm{P}$ apparently stabilized within $2 \mathrm{~d}$, it was noticeably lower than in the particulate fractions and equilibrated with those only after $14 \mathrm{~d}$. Three hours after the experiment began, the specific radioactivity in free phosphate $\mathrm{P}$ (as determined by ion chromatography) was $\sim 5$ times higher than that in the TP of the $<0.2-\mu \mathrm{m}$ fraction (Table 2 ), indicating a clear difference in labeling rates 
between phosphate and other dissolved $P$ pools. Later, the radioactivity in free phosphate $P$ was too low for determination due to the small sample size used for the ion chromatograph.

\section{Discussion}

To understand the results from the enclosure experiment in Mekkojärvi, it is necessary to consider the special limnological features of the lake. Along with its small size and sheltered position, the high water color from humic matter leached from the catchment area contributes to development of the very sharp chemical stratification of the water column (Fig. 1). In spring the plankton has a clear autotrophic phase immediately after ice melt; later, heterotrophic processes prevail (Salonen et al. 1992).

Allochthonous organic matter is a significant $\mathrm{C}$ source for planktonic food chains and thus, in spite of low autochthonous primary production, zooplankton is abundant. In the absence of predation by planktivorous fish, the large $D$. longispina is able to dominate the zooplankton and exerts very high grazing pressure on bacteria and algae (Salonen et al. 1992), as also indicated by the rapid accumulation of ${ }^{32} \mathrm{P}$ into zooplankton (Fig. 2). Thus, D. longispina largely dictates the structure of the microbial community in the plankton of Mekkojärvi, inducing selection for small fastgrowing nanoplankton species or for species that can avoid excessive grazing. The rather extreme characteristics of the lake present an opportunity to study plankton $P$ cycling under conditions simple enough to offer hope of understanding the basic mechanisms.

The time-courses of specific radioactivity and accumulation of ${ }^{32} \mathrm{P}$ in different size fractions and our limited ion chromatography data (Table 2) show that the free dissolved phosphate in the enclosure was mostly consumed by biological processes, leading to similar specific radioactivities in all organisms within 2$4 \mathrm{~d}$. The significantly lower specific radioactivity in dissolved $\mathrm{P}$ after the same time interval (Fig. 7) is evidently related to the high (70\%) proportion of DOP and suggests markedly slower turnover of the latter fraction and less tight coupling with biological $\mathrm{P}$ cycling than is the case for free phosphate.

According to the results from the seasonal study by Jones (1990), the 3-h phosphate turn- over time in this study may represent the shortest end of the range exhibited in Mekkojärvi. Indeed, determinations of phosphate turnover time with Mekkojärvi water samples taken from the open lake 1 week after the enclosure had been installed, and with high frequency sampling, showed a turnover time of $6 \mathrm{~h}$ (Jones unpubl. data).

Even a turnover time of $3 \mathrm{~h}$ is long compared with summer values reported in the literature and is not indicative of $\mathrm{P}$ limitation (e.g. Levine et al. 1986). Our results are consistent with the conclusion of Andersen et al. (1986) that detrital-based systems (as in Mekkojärvi; Salonen et al. 1992) are characterized by long nutrient turnover times. The observed stable $\mathrm{N}: \mathrm{P}$ atomic ratio of $\sim 14$ (Fig. 4) reflects a nearly balanced availability of both nutrients for the bacterial fraction, but for phytoplankton such a ratio might indicate slight $\mathrm{P}$ deficiency (Smith 1979). Because the $P$ level in bacteria may vary severalfold (e.g. Ohtake et al. 1985) and may be higher in relation to biomass than in other organisms (e.g. Olsen et al. 1986a; Tezuka 1990; Hessen and Andersen $1992)$, the $\mathrm{N}: \mathrm{P}$ ratio in the $0.2-1-\mu \mathrm{m}$ fraction cannot be used to assess the nutrient status of the phytoplankton fraction.

Many earlier studies (Rigler 1956; Currie and Kalff $1984 a, b$ ) have indicated that bacteria have the highest affinity for phosphate and are responsible for most of the epilimnetic phosphate uptake. However, such a conclusion could not be drawn from a Canadian wholelake experiment (Levine et al. 1986). In Mekkojärvi a high affinity for phosphate by bacteria could be seen from the development of the specific radioactivity (Fig. 7), although the time resolution at the beginning of the experiment was too crude to permit detailed comparison between the affinities of bacteria and phytoplankton. Using shorter time resolution experiments, Jones (1990) found that most ${ }^{33} \mathrm{PO}_{4}$ uptake in Mekkojärvi was into the bacterial size fraction $(0.2-2 \mu \mathrm{m})$ during the same time of summer as in our enclosure experiment. In Mekkojärvi, where fast growing, small heterotrophic flagellates are usually important, the apparent coincident radiolabeling of the $0.2-1$ - and $1-50-\mu \mathrm{m}$ size fractions might be partly explained by flagellate grazing on bacteria.

Simple size fractionation can, at best, only 
crudely differentiate major trophic levels in planktonic food chains and will not separate living from dead organic particles. In fact the similarity of the final specific radioactivities in all size fractions of the lake suggests little importance for detritus, although theoretically the results might also be explained by a similar turnover time (abiotic or biologically mediated) of $\mathrm{P}$ in detrital particles as in organisms. For unequivocal interpretation of the results, experiments with mixed populations should be made at species level (as we did with Daphnia) rather than by crude size fraction. Such an approach would greatly add to understanding the movements of $P$ in the microbial community where several metabolic types and trophic levels can occur in the same size class.

Even though the size of the enclosure was large and we sampled the lake extensively to get appropriate estimates for the population size of D. longispina (James and Salonen 1991), it is possible that patchy distribution of zooplankton resulted in a different density in the enclosure from that in the lake. Nevertheless, the number of animals in our samples left no doubt that the density of $D$. longispina was high in the enclosure. Finally, the specific radioactivities, which are central to the interpretation of our results, are completely independent of any density estimates. In summer the proportion of zooplankton P in TP of the epilimnion in the lake was undoubtedly so high that it should be taken into account when sampling for TP. Hessen et al. (1992) also found high proportions of $P$ (up to $>50 \%$ ) in zooplankton of some oligotrophic large $\left(2-8 \mathrm{~km}^{2}\right)$ lakes. Thus, the situation found in Mekkojärvi may be extreme but not exceptional.

The rapid attainment of equilibrium in the specific radioactivity of $D$. longispina in Mekkojärvi corresponds to a roughly $50 \%$ daily renewal of its $P$. This agrees with the results of Peters and Rigler (1973) who grew Daphnia rosea on a diet of yeast $(0.65 \% \mathrm{P}$ in dry wt) and found an approximately constant level of specific radioactivity after $3 \mathrm{~d}$ at $20^{\circ} \mathrm{C}$. Similarly, Lehman (1980) found 35-60\% daily turnover of $\mathbf{P}$ of Daphnia pulex grown on a green alga, Chlamydomonas reinhardtii. These results suggest that, although protozoans are often the most important mineralizers of $P$ (Andersen et al. 1986), in some circumstances larger zooplankton may play a similar role.
During mesocosm experiments with Mekkojärvi water (Salonen et al. 1992) conducted 1 week after installation of the enclosure, it was found that in a mesocosm from which zooplankton $>200 \mu \mathrm{m}$ had been removed, phosphate turnover time increased within $5 \mathrm{~d}$ to 3-fold that in a mesocosm which retained larger zooplankton (Jones unpubl. data). Such results clearly demonstrate the important role of larger zooplankton for regeneration of phosphate in this lake during summer.

Hessen (1990) observed that Daphnia magna keeps its $\mathrm{P}$ : dry wt ratio stable over a wide variation in food quantity as well as quality. Similarly, Hessen and Lyche (1991) found rather narrow variation in the relative $P$ level of D. longispina and Daphnia cucullata. When ingesting P-rich food, Daphnia would have to excrete the excess $P$ to maintain a stable chemical composition. Thus, the higher the concentration of $P$ in food of zooplankton, the higher the proportion recycled (Lehman and Naumoski 1985; Andersen et al. 1986; Olsen et al. $1986 b$ ). High concentrations of $\mathrm{P}$ in the food would contribute to high turnover in the $P$ pool of Daphnia. High $\mathrm{P}$ content relative to $\mathrm{C}$ in bacteria might be further emphasized by higher assimilation of $\mathbf{P}$ than $C$ (as suggested by Hessen and Andersen 1990). Excluding zooplankton, the total particulate biomass in the epilimnion of the lake was low, varying between 0.2 and $0.4 \mathrm{mg} \mathrm{C}$ liter ${ }^{-1}$ (Fig. 1), which may have been close to or less than the incipient limiting food level for Daphnia (Persson 1985). However, the POC availability to Daphnia was to some extent underestimated, because Whatman GF/C filters pass a high proportion of small bacteria.

Since $D$. longispina in Mekkojärvi contained 30-55 $\mu \mathrm{g} \mathrm{P}$ liter $^{-1}, \sim 20 \mu \mathrm{g} \mathrm{P}$ liter $^{-1}$ should have been taken daily by zooplankton. The latter value is consistent with the $\sim 37 \mu \mathrm{g} \mathrm{P}$ liter ${ }^{-1}$ $\mathrm{d}^{-1}$ uptake of phosphate by microorganisms, as estimated from a 3-h turnover time and the $4.6 \mu \mathrm{g} \mathrm{P}$ liter $^{-1}$ concentration of phosphate determined with ion chromatography. Thus, bacteria alone could have supplied the $P$ taken up by zooplankton. According to Tezuka (1990), phosphate regeneration by bacteria seems to be determined mainly by the $C: P$ ratio, so phosphate regeneration might not occur even at values $<106: 1$. Hence the high $\mathrm{C}$ : $P(>1,000: 1)$ in the DOM of Mekkojärvi sug- 
gests that bacteria are net consumers rather than mineralizers of phosphate.

Our results differ in some respects from those obtained in the whole-lake ${ }^{32} \mathrm{P}$ experiment of Levine et al. (1986). In eutrophic Lake 227 in Canada, $\mathrm{P}$ turnover time was 3 min compared with $\sim 3 \mathrm{~h}$ in Mekkojärvi. In lake 227 , most of the $P$ in organisms was in the $1-10-\mu \mathrm{m}$ size fraction, and small algae kept the concentration of phosphate extremely low. Although 1$50-\mu \mathrm{m}$ organisms rapidly took up phosphate in Mekkojärvi, their loss rate was highest (Fig. 7), indicating heavy grazing, and bacteria remained quantitatively the more important $P$ pool. However, among organisms in the lake, large zooplankton was the dominant $\mathrm{P}$ pool and was also a major factor regulating $P$ movement through its grazing, and hence influence, on plankton species composition. Consequently, in lakes with a high allochthonous load of organic matter, a long turnover time for phosphate and $\mathrm{P}$ sufficiency for plankton do not necessarily mean that phosphate partitioning between bacteria and algae is only a function of phosphate availability.

In Mekkojärvi top-down control of populations grazed by $D$. longispina in summer clearly favors dominance of small organisms with short generation times (Salonen et al. 1992), irrespective of $P$ availability. Hessen and Andersen (1990) found particularly rapid accumulation of $\mathrm{P}$ from bacteria to $D$. longispina and concluded that bacteria were its most important source of $P$ in a humic lake. In Lake 227 , zooplankton played a minor role in $P$ cycling; in contrast to our results, Levine et al. (1986) observed only slow stabilization of the specific radioactivity in zooplankton. After 2 weeks, specific radioactivity of the $>200-\mu \mathrm{m}$ size fraction was $<20 \%$ of that in TP, which might be explained by species composition (not reportcd by Levine et al. 1986). In Mekkojärvi and Lake 227, zooplankton food (bacteria or phytoplankton) may have been different. Probably the absence of fish in Mekkojärvi is important in allowing development of the high density of $D$. longispina.

The sedimentation rates of $P$ in Mekkojärvi (2.9\% of epilimnetic $\mathrm{P} \mathrm{d}^{-1}$ ) and Lake $227(\sim 2 \%)$ were rather similar and in accord with results reported elsewhere (Peters and Rigler 1973; Rigler 1973). In spite of this similarity, the mechanisms involved probably are different.
In Mekkojärvi, phytoplankton species are adapted to weak turbulence and are generally motile. Thus, with high grazing by $D$. longispina, it can be assumed that few algae sediment directly. Instead, the most probable mechanism leading to sedimentation is grazing followed by egestion of feces, as suggested by Peters and Rigler (1973). In contrast, in eutrophic Lake 227 many algae are nonmotile (Schindler et al. 1973) and depend more on turbulence to stay in the water column and hence may settle directly.

The results from our enclosure experiment suggest that both $\mathrm{P}$ cycling at the species level and vertical movements of $P$ require more attention in future studies. In Mekkojärvi, the depth to which the water column exhibited a homogeneous concentration of ions was essentially greater for $\mathrm{P}$ and $\mathrm{N}$ than for ions with less intense biological cycling (Fig. 1). That would be consistent with uptake of nutrients from the upper hypolimnion by migrating algae (Jones 1991).

The activity of zooplankton can also influence the vertical distribution of nutrients (Peters and Rigler 1973; Dini et al. 1987). If zooplankton migrate vertically, their feeding and subsequent excretion of nutrients may occur in different water layers. The rapid stabilization of the specific radioactivity in $D$. longispina at the beginning of the experiment, when the label had not yet significantly moved into the hypolimnion, suggests that it fed mainly in the epilimnion and moved $\mathrm{P}$ downward. Another explanation might be that in the hypolimnion, $D$. longispina grazed predominantly on algae that migrated diurnally and photosynthesized in the epilimnion.

In addition to feeding and excretion, Daphnia probably greatly influenced vertical movements of $\mathbf{P}$ through defecation. The latter led not only to increased sedimentation, but also to changes in the proportions of different $P$ pools at different depths. In Mekkojärvi, the hypolimnetic maximum of dissolved $P$ at the end of the experiment (Fig. 6) might have been caused by release of DIP and DOP from Daphnia feces that had settled to the hypolimnion. Such settlement is particularly likely because feces of cladocerans disintegrate rapidly to small particles (Olsen et al. 1986b). Direct release probably cannot explain the hypolimnetic maximum of dissolved $P$, because most 
animals did not stay in such deep water. In lakes with weak turbulence in the epilimnion, biologically mediated systems to redistribute $P$ vertically seem to override simple diffusion and turbulent movements. Such mechanisms may be important in understanding the species composition or production of a particular body of water (Jones 1991).

In conclusion, the results from our radiotracer study suggest that the pattern of $\mathrm{P}$ distribution and transformation in a small, humic forest lake was markedly different from those previously reported in the literature (e.g. Lean 1973; Levine et al. 1986) and widely cited as general models (e.g. Moss 1988). In particular, dissolved $P$ in humic lakes represents a relatively large part of the TP pool, although much of the DOP apparently interacts to only a limited extent, and slowly, with the other P compartments. In Mekkojärvi, a remarkable proportion of the particulate $P$ was associated with the macrozooplankton, but this phenomenon may be less marked in lakes with populations of planktivorous fish. Although Mekkojärvi is very different from large lakes, the general functions in the geochemistry of lakes are probably ubiquitous. Therefore, lakes like Mekkojärvi, with extremely simple communities, are good sites for studying these functions in more depth than is possible in complicated situations. Studies of both large and small lakes with variable allochthonous loads of organic matter are needed to better understand $\mathrm{P}$ cycling in lakes.

\section{References}

Andersen, O. K., J. C. Goldman, D. A. Caron, and M. R. DENNETT, 1986. Nutrient cycling in a microflagellate food chain. 3. Phosphorus dynamics. Mar. Ecol. Prog. Ser. 31: 47-55.

Bergström, I., A. Heinänen, AND K. SAlonen. 1986. Comparison of acridine orange, acriflavine, and bisbenzimide stains for enumeration of bacteria in clear and humic waters. Appl. Environ. Microbiol. 51:664667.

BLAKAR, I. A. 1979. A close interval water sampler with minimal disturbance properties. Limnol. Occanogr. 24: 983-988.

Currie, D. J., E. Bentzen, And J. KalfF. 1986. Does algal-bacterial phosphorus partitioning vary among lakes? A comparative study of orthophosphate uptake and alkaline phosphatase activity in freshwater. Can. J. Fish. Aquat. Sci. 43: 311-318.

, AND J. KALFF. 1984a. A comparison of the abilities of freshwater algae and bacteria to acquire and retain phosphorus. Limnol. Oceanogr. 29: 298-310.
- AND - $1984 b$. The relative importance of bacterioplankton and phytoplankton in phosphorus uptake in freshwater. Limnol. Oceanogr. 29: 31 1--321.

De HaAn, H., R. I. Jones, ANd K. Salonen. 1990. Abiotic transformations of iron and phosphate in humic lake water revealed by double isotopic labcling and gel filtration. Limnol. Occanogr. 35: 491-497.

Dini, M. L., J. O. Donnell, S. R. CARPenter, M. M. ElSER, AND A. M. BERgQuist. 1987. Daphnia size structure, vertical migration, and phosphorus redistribution. Hydrobiologia 150: 185-191.

Francko, D. A. 1986. Epilimnetic phosphorus cycling: Influence of humic materials and iron on coexisting major mechanisms. Can. J. Fish. Aquat. Sci. 43: 302310 .

- 1990. Alteration of bioavailability and toxicity by phototransformation of organic acids, p. 167-177. In E. M. Perdue and E. T. Gjessing [eds.], Organic acids in aquatic ecosystems. Wiley.

Heath, R. T. 1986. Dissolved organic phosphorus compounds: Do they satisfy planktonic phosphate demand in summer? Can. J. Fish. Aquat. Sci. 43: 343350 .

Hessen, D. O. 1990. Carbon, nitrogen and phosphorus status in Daphnia at varying food conditions. J. Plankton Res. 12: 1239-1249.

- AND T. ANDERSEN. 1990. Bacteria as a source of phosphorus for zooplankton. Hydrobiologia 206: 217223.

— AND - 1992. The algae-grazer interface: Feedback mechanisms linked to elemental ratios and nutrient cycling. Ergeb. Limnol. 35: 111-120.

$\longrightarrow$, T. ANDERSEN, AND B. FAAFENG. 1992. Zooplankton contribution to particulate phosphorus and nitrogen in lakes. J. Plankton Res. 14: 937-947.

$\longrightarrow$, AND A. LYCHE. 1991. Inter- and intraspecific variations in zooplankton element composition. Arch. Hydrobiol. 121: 343-353.

JAMES, M., AND K. SALONEN. 1991. Zooplankton-phytoplankton interactions and thcir importance in the phosphorus cycle of a polyhumic lakc. Arch. Hydrobiol. 123: 37-51.

Jones, J. G., B. M. Simon, And C. R. Cunningham. 1983. Bacterial uptake of algal extracellular products: An experimental approach. J. Appl. Bacteriol. 54: 355365.

JONES, R. I. 1990. Phosphorus transformations in the epilimnion of humic lakes: Biological uptake of phosphate. Freshwater Biol. 23: 323-337.

1991. Advantages of diurnal vertical migrations to phytoplankton in sharply stratified, humic forest lakes. Arch. Hydrobiol. 120: 257-266.

KankaAlA, P. 1988. The relative importance of algae and bacteria as food for Daphnia longispina (Cladocera) in a polyhumic lake. Freshwater Biol. 19: 285296.

LEAN, D. R. S. 1973. Phosphorus dynamics in lake water. Science 179: 678-680.

Lehman, J. T. 1980. Release and cycling of nutrients between planktonic algae and herbivores. Limnol. Occanogr. 25: 620-632.

$\longrightarrow$, AND T. NAIMOSKI. 1985. Content and turnover rates of phosphorus in Daphnia pulex: Effect of food quality. Hydrobiologia 128: 119-125. 
Levine, S. N., M. P. Stainton, And D. W. Schindler. 1986. A radiotracer study of phosphorus cycling in a eutrophic Canadian shield lake, Lake 227, northwestern Ontario. Can. J. Fish. Aquat. Sci. 43: 366378.

Moss, B. 1988. Ecology of fresh waters, 2nd ed. Blackwell.

Murphy, J., AND J. P. Riley. 1962. A modified single solution method for the determination of phosphate in natural waters. Anal. Chim. Acta 27: 31-36.

Ohtake, H., K. Takahashi, Y. Tsuzuki, and K. Toda. 1985. Uptake and release of phosphate by a pure culture of Acinetobacter calcoaceticus. Water Res. 19: 1587-1594.

OLSEN, Y., AND OTHERS. $1986 a$. Dependence of the rate of release of phosphorus by zooplankton on the P:C ratio in the food supply, as calculated by a recycling model. Limnol. Oceanogr. 31: 34-44.

K. M. VARUm, AND A. Jensen. 1986b. Some characteristics of the carbon compounds released by Daphnia. J. Plankton Res. 8: 505-517.

Persson, G. 1985. Clearance rates of crustacean microfiltrators: The nature of in situ rate depressions in a fertilized oligotrophic lake in the Kuokkel area, northcrn Sweden. Int. Rev. Gesamten Hydrobiol. 70: 335358.

Peters, R. H., ANd F. H. Rigler. 1973. Phosphorus release by Daphnia. Limnol. Oceanogr. 18: 821-839.

Rigler, F. H. 1956. A tracer study of the phosphorus cycle in lake water. Ecology 37: 550-562. . 1973. A dynamic view of the phosphorus cycle in lakes, p. 539-572. In E. J. Griffith et al. [eds.], Environmental phosphorus handbook. Wiley.
RyHÄNEN, R. 1968. Die Bedeutung der Humussubstanzen im stoffhaushalt der Gewässer Finnlands. Mitt. Int. Ver. Theor. Angew. Limnol. 14, p. 168-178.

SALONEN, K. 1979. A versatile method for the rapid and accurate determination of carbon by high temperature combustion. Limnol. Oceanogr. 24: 177-183.

- AND OTHERS. 1992. Planktonic food chains of a highly humic lake. 2. A mesocosm experiment in summer during the dominance of heterotrophic processes. Hydrobiologia 229: 143-157.

SCHINDLER, D. W. 1977 . Evolution of phosphorus limitation in lakes. Science 195: 260-262.

- - AND OTHERS. 1973. Eutrophication of Lake 227 by addition of phosphate and nitrate: The second, third, and fourth years of the enrichment 1970, 1971, and 1972. J. Fish. Res. Bd. Can. 30: 1415-1440.

SMITH, V. H. 1979. Nutrient dependence of primary productivity in lakes. Limnol. Oceanogr. 24: 1051-1064.

Stewart, A. J., AND R. G. Wetzel. 1982. Influence of dissolved humic materials on carbon assimilation and alkaline phosphatase activity in natural algal-bacterial assemblages. Freshwater Biol. 12: 369-380.

TEZUKA, Y. 1990. Bacterial regeneration of ammonium and phosphate as affected by the carbon: nitrogen: phosphorus ratio of organic substrates. Microb. Ecol. 19: 227-238. 